\title{
Kajian Pengaruh Pemberian Pakan Lengkap Berbahan Baku Fermentasi Tongkol Jagung terhadap Produktivitas Ternak Sapi PO di Kabupaten Majalengka
}

\author{
Study on Productivity of PO Cattle Provided by Complete Feed Containing \\ Fermented Corn-Cobs in Majalengka District, West Java
}

\section{E. Gustiani dan K. Permadi}

Balai Pengkajian Teknologi Pertanian Jawa Barat

email: fathbian@yahoo.com

(Diterima: 5 November 2014; Disetujui: 2 Februari 2015)

\begin{abstract}
ABSTRAK
Tongkol jagung merupakan produk samping pertanian yang dapat dimanfaatkan sebagai bahan pakan alternatif untuk ternak ruminansia. Nilai nutrisi serta palatabilitasnya rendah, sehingga perlu diupayakan dengan pengolahan terlebih dahulu. Tujuan pengkajian yaitu untuk mengetahui pengaruh pemberian pakan lengkap berbahan baku fermentasi tongkol jagung terhadap produktivitas ternak sapi. Pengkajian dilaksanakan bulan Oktober 2014 di Kelompok Tani Ternak Lengo, Kelurahan Sindangkasih, Kecamatan Majalengka.Perlakuan dibagi kedalam dua kelompok. Perlakuan $\mathrm{A}=$ kontrol/kebiasaan peternak dan $\mathrm{B}=$ pemberian pakan lengkap dengan bahan baku tongkol jagung fermentasi + leguminosa + dedak + mineral. Parameter yang diamati adalah 1 ). Kualitas fermentasi tongkol jagung, 2) Kualitas pakan lengkap, 3) Bobot badan ternak, 4) pertambahan bobot badan harian (pbbh). Data yang diperoleh dianalisis dengan uji t dan secara deskriptif. Hasil pengkajian menunjukkan bahwa: 1) fermentasi pada tongkol jagung meningkatkan kandungan protein kasar dari 1,92 menjadi 2,4\%; 2) Kandungan Protein Kasar Pakan Lengkap 11,76\%; dan 3) pemberian pakan lengkap pada sapi PO di Kelompok Lengo menunjukkan rataan pertambahan berat badan harian (pbbh) yang lebih tinggi $(0,4-0,82 \mathrm{~kg} / \mathrm{ekor} / \mathrm{hari})$ dibandingkan dengan perlakuan pada kelompok A/kontrol $(0,10-0,39 \mathrm{~kg} / \mathrm{ekor} / \mathrm{hari})$.
\end{abstract}

Kata kunci : pakan lengkap, tongkol jagung, produktivitas, sapi PO

\begin{abstract}
Although corn-cobs as an agricultural by products could be used as an alternative feed ingredient for ruminants, its low nutritional value and palatability require an early processing. The study aimed at determining the effect of providing complete feed containing fermented corn cobs on beef cattle the productivity at Lengo livestock farmers group in Sindangkasih Village, Majalengka. The study was carried out on October 2014 with two groups of treatment. Treatment A cattle fed normally as farmers usual habits categorized as a control. Treatment B, cattle fed raw materials with fermented corn cob + legume + bran + minerals. Measured parameters consisted of 1) quality of corn cob fermentation; 2) quality of complete feed, 3) cattle body weight, and 4) Average daily gain $(A D G)$. The collected data were analyzed by $t$-test and descriptive explanation. The results showed the following points: 1) the fermentation of corn cobs increased the crude protein content from 1.92 to 2.45\%;2) complete feed contained crude protein 11,76\%; and 3) the provision of complete feed for PO cattle at Lengo livestock farmer's group showed a higher the average daily gain $(0,48-0,82 \mathrm{~kg} / \mathrm{head} /$ day) compared to the control (treatment A) at (0,10-0,39 $\mathrm{kg} / \mathrm{head} / \mathrm{day}$ )
\end{abstract}

Keywords : complete feed, corn cob, productivity, PO cattle 


\section{PENDAHULUAN}

Salah satu penyebab rendahnya produktivitas ternak ruminansia di Indonesia adalah kurang tersedianya bahan pakan berkualitas secara berkelanjutan dalam jumlah cukup. Pakan yang berkualitas dan tersedia kontinyu sepanjang tahun merupakan salah satu faktor penting dalam upaya pengembangan peternakan (Hastuti et al., 2011). Penyediaan pakan bagi ternak ruminansia dapat berasal dari sisa hasil pertanian, perkebunan maupun agroindustri. Pakan yang diberikan pada ternak harus memperhatikan ketersediaan dan efisiensi biaya, sehingga perlu adanya pemanfaatan limbah sebagai alternatif pakan ternak yang murah dan mudah dicari (Herry et al., 2013). Salah satu limbah hasil pertanian dan perkebunan yang mempunyai potensi cukup besar di Jawa Barat adalah tongkol jagung. Menurut Yulistiani (2010) tongkol jagung merupakan hasil sisa tanaman pertanian yang cukup melimpah tetapi masih jarang digunakan sebagai bahan pakan ternak. Luas lahan panen tanaman jagung di Provinsi Jawa Barat tahun 2013 yaitu 152.923 ha, dengan produktivitas $72,06 \mathrm{kw} / \mathrm{ha}$ dan peningkatan produksi selama 5 tahun (2009 - 2013) sebesar 28,53\% yaitu dari 787.599 ton menjadi 1.101.998 ton (Badan Pusat Statistik Jawa Barat, 2013).

Kabupaten Majalengka merupakan salah satu penghasil jagung urutan kedua terbesar di Jawa Barat setelah Kabupaten Garut. Luas tanam jagung di Kabupaten Majalengka pada tahun 2013 sebesar 15.045 ha, luas panen 17.137 ha, produksi jagung 119.701 ton dan produktivitas 6,99 ton/ha (Dinas Pertanian dan Perikanan Kab. Majalengka, 2013). Seiring dengan peningkatan taraf hidup ekonomi masyarakat dan kemajuan industri pakan ternak, kebutuhan jagung terus meningkat sehingga perlu upaya peningkatan produksi melalui sumber daya manusia dan sumber daya alam, ketersediaan lahan maupun potensi hasil dan teknologi (Carolina et al., 2011).

Peningkatan produksi jagung diikuti dengan peningkatan hasil samping dalam bentuk tongkol jagung. Tongkol jagung atau janggel adalah bagian dari buah jagung sete- lah biji dipipil, dan merupakan sumber serat yang dapat dijadikan bahan pakan alternatif, berpotensi untuk dimanfaatkan sebagai sumber serat pengganti rumput pada pakan ternak ruminansia (Yulistiani dan Haryanto, 2013). Namun limbah tersebut belum dimanfaatkan secara optimal sebagai bahan pakan ternak.

Permasalahan utama belum dimanfaatkannya tongkol jagung sebagai pakan ternak adalah karena kadar nutrisinya rendah, yaitu kadar proteinnya $4,64 \%$, lignin $>10 \%$ dan selulosa yang tinggi (Ramirez et al., 2007). Kandungan nutrisi tongkol jagung berdasarkan analisis di Laboratorium Ilmu Makanan Ternak meliputi kadar air $29,54 \%$, bahan kering $70,45 \%$, protein kasar $2,67 \%$ dan serat kasar 46,52\% dalam $100 \%$ bahan kering (BK). Rendahnya kandungan nutrisi dari limbah pertanian disebabkan karena kandungan nutrien tanaman dalam batang dan daun telah berpindah ke dalam produk utama berupa biji atau buah. Oleh karena itu, dalam pemanfaatannya sebagai bahan pakan, perlu dicarikan teknologi pengolahan tongkol jagung yang dapat meningkatkan kualitas nutrisi dan kecernaannya. Pengurangan partikel pakan dengan penggilingan merupakan salah satu perlakuan pradigesti pada pakan berserat secara fisik yang mampu meningkatkan kecernaan, sedangkan secara kimiawi dapat dilakukan dengan proses fermentasi untuk meningkatkan nilai nutrisi bahan pakan. Penggunaan tongkol jagung sebagai sumber serat kasar dapat dikombinasikan dengan bahan pakan lain dengan kandungan protein dan energi yang tinggi sehingga diperoleh pakan dengan kandungan nutrisi yang baik atau dapat disebut sebagai pakan lengkap (Complette Feed).

Pengembangan teknologi pakan lengkap merupakan metode atau teknik pembuatan pakan dimana sumber serat kasar dan sumber protein dicampur menjadi homogen melalui proses perlakuan fisik dan suplementasi yang dikemas dalam bentuk tertentu agar pemberian kepada ternak efektif dan memudahkan dalam penyimpanan. Pemberian pakan lengkap diharapkan mampu mencukupi kebutuhan nutrisi ternak dan dapat meningkatkan efisiensi usaha 
ternak sapi potong sehingga pada usaha penggemukkan ternak sapi potong dapat ditunjukkan dengan pertambahan bobot badan yang optimal. Pengkajian bertujuan untuk mengetahui pertambahan bobot badan harian (pbbh) ternak yang diberikan pakan lengkap dengan bahan baku tongkol jagung fermentasi.

\section{METODOLOGI}

Pengkajian dilakukan di Kelompok Tani Ternak Lengo, Kelurahan Sindangkasih, Kecamatan Majalengka, Kabupaten Majalengka pada bulan Oktober 2014. Pengkajian menggunakan 14 ekor ternak sapi potong yang berumur 6-8 bulan dengan berat badan yang relatif seragam. Ternak tersebut dibagi ke dalam dua kelompok ( 2 perlakuan). Perlakuan A (kontrol/kebiasaan peternak) diberi pakan hijauan (rumput lapangan atau rumput gajah) dan limbah pertanian berupa jerami padi/daun jagung sebanyak 20-25 kg/ekor. Sumber protein atau pakan tambahan berupa leguminosa atau limbah dari pabrik tahu tidak diberikan setiap hari. Perlakuan $\mathrm{B}=$ diberikan pakan lengkap dengan bahan baku tongkol jagung fermentasi + leguminosa + dedak + mineral yang dicampur secara homogen dan diberikan dalam bentuk kering sebesar 3\% dari bobot badan sedangkan hijauan (rumput lapang) sebanyak $10 \mathrm{~kg} / \mathrm{ekor}$ (perbandingan antara pakan lengkap dan hijauan sekitar 30 : 70). Pakan lengkap diberikan 2 kali sehari yaitu pada pagi dan sore hari.

Tahapan pembuatan pakan lengkap terdiri dari: 1) penggilingan tongkol jagung untuk mendapatkan ukuran yang lebih kecil, 2) fermentasi tongkol jagung menggunakan larutan stater (Trichoderma) dengan perbandingan 1 liter larutan stater untuk 1 kwintal tongkol jagung giling. Proses fermentasi tongkol jagung berlangsung selama 3 hari, yaitu dengan cara menumpuk tongkol jagung yang sudah digiling setinggi $\pm 20 \mathrm{~cm}$, kemudian disemprot dengan larutan stater (Trichoderma). Diamkan dalam keadaan terbuka selama 3 hari agar proses fermentasi berlangsung dengan baik (fermentasi berlangsung secara aerob). 3) leguminosa dilayukan dengan cara dijemur
Tabel 1. Komposisi pakan lengkap

\begin{tabular}{llc}
\hline No & \multicolumn{1}{c}{ Bahan baku } & $\begin{array}{c}\text { Jumlah } \\
(\%)\end{array}$ \\
\hline 1. & Tongkol jagung fermentasi & 40 \\
2. & Dedak & 42 \\
3. & Leguminosa & 17 \\
4. & Mineral & 1 \\
\hline & Jumlah & 100 \\
\hline
\end{tabular}

atau diangin-anginkan sampai kadar air mencapai $10-12 \%$ dan, 4) pencampuran bahanbahan pakan lengkap hingga homogen. Komposisi pakan lengkap disajikan pada Tabel 1.

Parameter yang diukur adalah 1). Kualitas fermentasi tongkol jagung; 2) Kualitas pakan lengkap; 3) Bobot badan ternak, dan 4). Pertambahan bobot badan harian $(\mathrm{PBBH})$. Data pertambahan bobot badan $(\mathrm{PBBH})$ dihitung menggunakan rumus :

$$
\text { PBBH }=\frac{\text { (BB akhir }-\mathrm{BB} \text { awal) }}{\text { lama pengamatan (hari) }}
$$

Keterangan:

PBBH = pertambahan bobot badan harian (kg/ekor/hari)

$\mathrm{BB}=$ bobot badan $(\mathrm{kg})$

Data yang terkumpul ditabulasi dalam master table, selanjutnya dilakukan pengolahan data dengan format yang telah ditetapkan untuk mempermudah analisis. Data dianalisis menggunakan uji t dan secara deskriptif.

\section{HASIL DAN PEMBAHASAN}

\section{Kandungan Nutrisi Bahan Pakan Lengkap}

Tongkol jagung mengandung lignoselulosa yang terdiri dari lignin, selulosa dan hemiselulosa. Janggel atau tongkol kosong berbentuk batang berukuran cukup besar, sehingga tidak dapat dikonsumsi ternak jika diberikan langsung, sehingga, untuk memberikannya perlu penggilingan terlebih dahulu (Suhartanto et al., 2003). Peningkatan kualitas nutrisi tongkol jagung dilakukan melalui pengolahan secara fisik (pengurangan ukuran partikel) dan secara kimia (proses fermentasi). Nilai nutrisi tongkol jagung fermentasi yang 
digunakan dalam penyusunan pakan lengkap di Kelurahan Sindangkasih disajikan pada Tabel 2.

Kandungan serat kasar pada tongkol jagung baik yang difermentasi maupun non fermentasi cukup tinggi yaitu berkisar antara 30-32,83\%. Menurut Despal (2000) serat kasar memiliki hubungan yang negatif dengan kecernaan. Semakin rendah serat kasar maka semakin tinggi kecernaan ransum. Fermentasi tongkol jagung meningkatkan kandungan protein kasar dari $1,92 \%$ menjadi $2,45 \%$ dan menurunkan kandungan serat kasar dari $32,83 \%$ menjadi $30,04 \%$.

Kadar protein kasar tongkol jagung fermentasi dalam pengkajian ini lebih rendah dari hasil penelitian Ruswendi (2011) yang dapat meningkatkan kandungan protein kasar dari 5,62 menjadi 7,68\%. Hal ini disebabkan karena adanya perbedaan faktor genotipe (varietas dan kultivar), cara pengambilan sampel dan pengolahan yang mempengaruhi komposisi kimia suatu pakan.Peningkatan protein kasar tongkol jagung terjadi sebagai akibat adanya suplementasi nitrogen dalam bentuk urea yang terkandung pada biostater (dekomposer) yang digunakan pada proses fermentasi. Peningkatan protein kasar pada tongkol jagung hasil fermentasi dapat terjadi juga akibat adanya pertumbuhan dan perkembangbiakan mikroba dalam biostater yang memberikan sumbangan terhadap peningkatan kandungan protein kasar produk fermentasi. Demikian pula pada kandungan lemak tongkol jagung fermentasi mengalami kenaikan dari 0,39 menjadi 0,49 . Hal ini diduga bahwa proses fermentasi dapat menimbulkan perubahan fisik dan kimia dari senyawa organik substrat akibat aktifitas mikroba.

Berkaitan dengan kandungan protein kasar tongkol jagung, kandungan protein yang relatif rendah dapat dikoreksi dengan kombinasi pemberian bahan pakan sumber protein dan mineral. Namun pemilihan sumber protein harus memperhatikan karakteristik dari sumber protein yang akan digunakan disamping mempertimbangkan harga bahan pakan agar mudah terjangkau (Natsir, 2012). Suhartanto et al. (2003) menyatakan pemanfaatan tongkol jagung sebagai pakan ternak ruminansia memerlukan suplementasi pakan sumber energi dan protein, karena kualitasnya rendah. Suplementasi nutrien baik energi maupun protein secara bersama-sama dimaksudkan untuk optimasi pertumbuhan mikrobia agar pemanfaatan pakan berserat dapat optimal.

Tabel 2. Kandungan nutrisi tongkol jagung fermentasi dan non fermentasi di Kelompok Tani Ternak Lengo, Kelurahan Sindangkasih, Kecamatan Majalengka, Kab Majalengka

\begin{tabular}{|c|c|c|c|c|c|c|}
\hline No & Bahan Pakan & $\begin{array}{c}\text { Kadar } \\
\text { Air }\end{array}$ & $\begin{array}{c}\text { Protein } \\
\text { Kasar }\end{array}$ & $\begin{array}{c}\text { Lemak } \\
\text { Kasar }\end{array}$ & $\begin{array}{c}\text { Serat } \\
\text { Kasar }\end{array}$ & KH/Pati \\
\hline & & 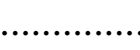 & &.$\%$ & .......... & ....... \\
\hline 1. & Tongkol jagung fermentasi & 2,63 & 2,45 & 0,49 & 30,04 & 15,22 \\
\hline 2. & Tongkol jagung non fermentasi & 3,09 & 1,92 & 0,39 & 32,83 & 15,54 \\
\hline
\end{tabular}

Sumber : Hasil Analisis Proksimat Balai Penelitian Sayuran, 2014

Tabel 3. Komposisi kimia bahan pakan lengkap di Kelompok Tani Ternak Lengo, Kelurahan Sindangkasih, Kecamatan Majalengka, Kabupaten Majalengka

\begin{tabular}{|c|c|c|c|c|c|}
\hline No & Bahan Pakan & Kadar Air & Protein Kasar & Lemak Kasar & Serat Kasar \\
\hline & & & & $\% \ldots \ldots \ldots$ & \\
\hline 1. & Tongkol jagung fermentasi & 2,63 & 2,45 & 0,49 & 30,04 \\
\hline 2. & Dedak Padi & 8,71 & 9,96 & 2,32 & 18,5 \\
\hline 3. & Leguminosa & 7,98 & 23,11 & 4,43 & 13,3 \\
\hline
\end{tabular}

Sumber : Laboratorium Balai Penelitian Sayuran, 2014 
Tabel 4. Kandungan nutrisi pakan lengkap berbahan baku fermentasi tongkol jagung, dedak dan leguminosa

\begin{tabular}{llc}
\hline No & \multicolumn{1}{c}{ Uraian } & Kandungan Nutrisi $(\%)$ \\
\hline 1. & Kadar air & 9,60 \\
2. & Abu total & 10,16 \\
3. & Protein kasar & 11,76 \\
4. & Serat kasar & 12,82 \\
5. & Lemak & 2,15 \\
\hline
\end{tabular}

Sumber : Laboratorium Balai Penelitian Sayuran, (2014)

Dalam pengkajian ini kandungan serat kasar pada tongkol jagung sebagai bahan baku pembuatan pakan lengkap disuplementasi dengan dedak padi dan leguminosa yang memiliki kandungan protein kasar yang tinggi. pakan lengkap (Complette Feed) merupakan metode atau teknik pembuatan pakan dimana hijauan (sumber serat) dan konsentrat dicampur menjadi homogen melalui proses perlakuan fisik dan suplementasi yang dikemas dalam bentuk tertentu agar pemberian kepada ternak efektif dan memudahkan dalam penyimpanan. Lammers et al. (2003) menyatakan bahwa pakan lengkap mempunyai pengertian sebagai suatu jenis pakan yang dirancang untuk produk komersial bagi ternak ruminansia dan didalamnya sudah mengandung bahan hijauan maupun konsentrat dalam imbangan memadai.

Kandungan nutrisi pakan lengkap dengan bahan baku fermentasi tongkol jagung, dedak dan leguminosa disajikan pada Tabel 4. Kandungan protein kasar pakan lengkap sebesar $11,76 \%$. Tingginya kadar protein kasar pada pakan lengkap diduga berasal bahan tambahan sumber protein dari leguminosa yang memiliki kadar protein kasar yang tinggi. Penggunaan pakan lengkap pada ternak sangat relevan untuk memudahkan pemenuhan kebutuhan nutrisi, dan pada saat yang sama mampu menyumbang kebutuhan serat (NDF) yang penting bagi stabilitas ekosistem rumen. $\mathrm{Pa}-$ kan lengkap juga lebih menjamin meratanya distribusi asupan harian ransum, agar fluktuasi kondisi ekosistem di dalam rumen diminimalisir (Tafaj et al., 2007).

Pengaruh pemberian pakan lengkap terhadap rataan bobot badan dan pertambahan bobot badan harian pada kedua kelompok ternak disajikan pada Tabel 5. Tabel 5 menunjukkan bahwa terdapat variasi perubahan bobot badan dan pertambahan bobot badan ternak pada kedua perlakuan. Terjadinya perbedaan

Tabel 5. Pengaruh pemberian pakan lengkap terhadap rataan bobot badan dan pertambahan bobot badan harian (pbbh) ternak sapi

\begin{tabular}{cccc}
\hline Peubah & \multicolumn{2}{c}{ Perlakuan } & \multirow{2}{*}{ T hit } \\
\cline { 2 - 3 } & A (kontrol) & B (pemberian complette feed) & \\
Berat Badan (kg) & & & 141,57 \\
Bobot awal & 140,14 & 148,86 & tn \\
Minggu ke-2 & 143,57 & 155,57 & tn \\
Minggu ke-4 & 145,14 & 171,28 & tn \\
Minggu ke-6 & 149,71 & 187,71 & tn \\
Minggu ke-8 & 162,14 & 195,14 & $*$ \\
Minggu ke 10 & 162,57 & & $*$ \\
Pertamban Berat Badan Harian & & 0,52 & $*$ \\
kg/ekor/hari) & 0,10 & 0,48 & tn \\
Minggu ke-2 & 0,23 & 0,68 & $*$ \\
Minggu ke-4 & 0,15 & 0,82 & $*$ \\
Minggu ke-6 & 0,39 & 0,53 & \\
Minggu ke-8 & 0,17 & & \\
Minggu ke 10 & & & \\
\hline
\end{tabular}

Keterangan: $*$ = berbeda nyata, $\quad$ tn $=$ berbeda tidak nyata 
pbbh antara kedua perlakuan kemungkian disebabkan compensatory growth, Ternak yang terbiasa mengkonsumsi pakan dengan kualitas nutrisi yang rendah dan bobot awal yang rendah bila diberi pakan dengan kualitas baik akan cenderung mengalami pertambahan berat badan dengan cepat untuk mencapai bobot maksimum sesuai dengan kemampuan genetiknya. Perlakuan pemberian pakan lengkap menunjukkan rataan pertambahan berat badan (pbbh) yang lebih tinggi $(0,48-0,82 \mathrm{~kg} / \mathrm{ekor} /$ hari) dibandingkan dengan perlakuan peternak /kontrol (0,10-0,39 kg/ekor/hari).

Pertambahan berat badan merupakan salah satu indikator yang dapat digunakan untuk menilai kualitas pakan ternak. Menurut Mc.Donald et al. (2002) pertumbuhan ternak ditandai dengan peningkatan ukuran, bobot dan adanya perkembangan. Pengukuran bobot badan berguna untuk penentuan tingkat konsumsi, efisiensi pakan dan harga ternak untuk ternak penggemukkan (Parakkasi, 1999).

\section{KESIMPULAN}

1. Proses Fermentasi pada tongkol jagung dapat meningkatkan kandungan protein kasar dari 1,92 menjadi 2,45\%

2. Kandungan Nutrisi Pakan Lengkap: Protein Kasar 11,76\%, Serat Kasar 12,82\% dan Lemak 2,15\%

3. Pemberian pakan lengkap dengan bahan baku fermentasi tongkol jagung (Kelompok B) pada sapi PO di Kelompok Lengo Kelurahan Sindangkasih Kelurahan Majalengka menunjukkan rataan pertambahan berat badan harian (pbbh) yang lebih tinggi $(0,48-0,82 \mathrm{~kg} / \mathrm{ekor} / \mathrm{hari})$ dibandingkan dengan perlakuan pada kelompok A/kontrol $\quad(0,10-0, \quad 39$ $\mathrm{kg} / \mathrm{ekor} / \mathrm{hari}$ ).

\section{DAFTAR PUSTAKA}

Badan Pusat Statistik Jawa Barat. 2013. Jawa Barat Dalam Angka.

Carolina B.D. L. Pakasi, Pangemanan, R. Juliana, Mandei, N.I. Nineteen dan Rompas. 2011. Efisiensi penggunaan faktor produksi pada usahatani jagung di kecamatan remboken kabupaten minahasa (studi perbandingan peserta dan bukan peserta sekolah lapang pengelolaan tanaman terpadu). ASE 7 (2) : $51-60$.

Despal. 2000. Kemampuan komposisi kimia dan kecernaan in vitro dalam mengestimasi kecernaan in vivo. Media Peternakan 23 (3): $84-88$

Hastuti, D. Shofia Nur A, dan Baginda Iskandar M. 2011. Pengaruh perlakuan teknologi amofer (amoniasi fermentasi) pada limbah tongkol jagung sebagai alternatif pakan berkualitas ternak ruminansia. J. Ilmu Pertanian 7 (1) : 55-65

Dinas Pertanian dan Perikanan Kabupaten Majalengka. 2014. Majalengka dalam angka 2014. Pemerintah Kabupaten Majalengka

Yulistiani, D. 2010. Fermentasi tongkol jagung (kecernaan >50\%) dalam ransum komplit domba komposit sumatera dengan laju pertumbuhan $>125$ gram/hari. program insentif riset terapan. Balai Penelitian Ternak. Bogor

Yulistiani, D dan Haryanto B. 2013. Nilai nutrisi tongkol jagung yang difermentasi menggunakan mikroba rumen sebagai sumber inokulan. Seminar Nasional Teknologi Peternakan dan Veteriner 2013

Suprapto, H. FM. Suhartati dan Titin Widiyastuti. 2013. Kecernaan serat kasar dan lemak kasar complete feed limbah rami dengan sumber protein berbeda pada kambing peranakan etawa lepas sapih. Jurnal Ilmiah Peternakan 1(3) : 938-946

Lammers B.P., A.J. Heindrichs and V.A. Ishler. 2003. Use of Total Mixed Rations (TMR) for Dairy Cows. Dairy Cattle Feeding and Management. Departement of Dairy and Animal 
Science. The Pensilvania State University

Mc Donald, P., R.A. Edward, J.F.D. Greenhalgh and C.A. Morgan. 2002. Animal Nutrition. $6^{\text {th }}$ Edition. Ashford Color Pr., Gosport

Natsir, A. 2012. Efficient Utilization of Fibre for Ruminants. Masagena Press.

Parakkasi, A. 1999. Ilmu Nutrisi dan Makanan Ternak Ruminan. Penerbit Universitas Indonesia, Jakarta

Ramirez, G.R, J.C. Aguilera-Gonzalez, G. Garcia-Diaz and A.M. NunezGonzales. 2007. Effect of urea treatment on chemical composition and digestion of cenchrus ciliaris and cynodon dactylon hays and zeamays residues. J. Anim. Vet. Adv. 6: 10361041

Ruswendi. 2011. teknologi pakan berkualitas untuk sapi potong. balai pengkajian teknologi pertanian provinsi bengkulu. badan penelitian dan pengembangan pertanian

Tafaj, M.Q. Zebeli, C.H. Baes, H. Steingass and W.D. Rochner. 2007. A metaanalysis examining effect of particle size of total mix ration on intake, rumen digestion and milk production in high-yielding dairy cows at early lactation. Anim. Feed. Sci. Technol. 138: $137-161$

Suhartanto, B., B.P. Widyobroto, dan R. Utomo. 2003. Produksi ransum lengkap (complete feed) dan suplementasi undegraded protein untuk meningkatkan produksi dan kualitas daging sapi potong. Laporan Penelitian Ilmu Pengetahuan Terapan (Hibah Bersaing X/3). Lembaga Penelitian Universitas Gadjah Mada. Yogyakarta 